\title{
Studies on Pantothenic Acid Intake
}

\section{Pantothenic Acid Intake of Farming and Fishing Villagers}

\author{
By \\ Kôzô Ishiguro \\ Department of Hygiene, Tohoku University School of Medicine \\ Director: Prof. E. Takahashi
}

(Received for publication, October 24, 1962)

In the previous paper of this series, ${ }^{1)}$ the author has reported the results of his investigation on the contents of free pantothenic acid $(\mathrm{Pa} \mathrm{A})$ and total pantethine (conjugated pantothenic acid of and above pantetheine level) in various articles of food.

In this report the results of a survey of the difference in $\mathrm{Pa} \mathrm{A}$ intake of inhabitants of an agricultural and a fishing village in northern Honshu are studied based on the previously reported results.

The subjects of survey consisted of the members of 30 families living in an inland village of single crop rice field and 37 families on an island living on fishing. In 1959, the daily diet of these subjects was observed for 3 days each in the 4 seasons and the daily intake of free $\mathrm{Pa} \mathrm{A}$ and total pantethine per adult was estimated.

\section{RESULTS}

As shown in Table I and Fig. 1 the daily intake per adult subject of free Pa A was $3.8-5.5 \mathrm{mg}$, showing no difference between the farming and fishing villagers. The intake was always the largest in autumn. The intake of total panthethine was always larger among the fishers than the farmers, especially significantly in autumn and winter. By season, the intake was the largest in autumn, as in the case of free $\mathrm{Pa} \mathrm{A}$. In the farming village, the intake of total pantethine decreased below $1.0 \mathrm{mg}$ per day in spring and winter.

In Tables II and III are shown the intake and intake ratio of $\mathrm{Pa} \mathrm{A}$ and total pantethine from food articles of different classes, respectively. Free $\mathrm{Pa} \mathrm{A}$ was derived mainly from cereals and vegetables to the extent of 50-60 per cent of the total intake, both in the farming and the fishing villages. The next source was eggs and legumes in the farming village and fishes in the fishing village. However, 
TABLE I. Seasonal Variation of the Intake of Pantothenic Acid of the Farming and Fishing Villagers (mg/day, adult)

A. Free pantothenic acid

\begin{tabular}{l|c|c|c|c}
\hline & \multicolumn{2}{|c|}{ Farming village } & \multicolumn{2}{c}{ Fishing village } \\
\cline { 2 - 5 } & $\mathrm{M}_{ \pm \mathrm{m}}$ & $\mathrm{S.D}$ & $\mathrm{M} \pm \mathrm{m}$ & S.D. \\
\hline Spring & $4.25 \pm 0.18$ & 1.03 & $3.84 \pm 0.16$ & 1.02 \\
Summer & $4.66 \pm 0.17$ & 0.93 & $4.46 \pm 0.22$ & 1.38 \\
Autumn & $5.33 \pm 0.28$ & 1.53 & $\mathbf{5 . 4 7} \pm 0.23$ & 1.39 \\
Winter & $4.48 \pm 0.25$ & 1.36 & $\mathbf{4 . 2 7} \pm 0.23$ & 1.38
\end{tabular}

B. Total pantethine

\begin{tabular}{l|l|l|l|l} 
Spring & $0.86 \pm 0.06$ & 0.37 & $0.89 \pm 0.03$ & 0.23 \\
Summer & $1.20 \pm 0.07$ & 0.40 & $1.36 \pm 0.06$ & 0.42 \\
Autumn & $1.42 \pm 0.09$ & 0.50 & $2.00 \pm 0.11$ & 0.70 \\
Winter & $0.89 \pm 0.05$ & 0.31 & $1.72 \pm 0.17$ & 1.05
\end{tabular}

Farming village: 30 families; fishing village: 37 families.

M: mean; m: mean error; S.D.: standard deviation

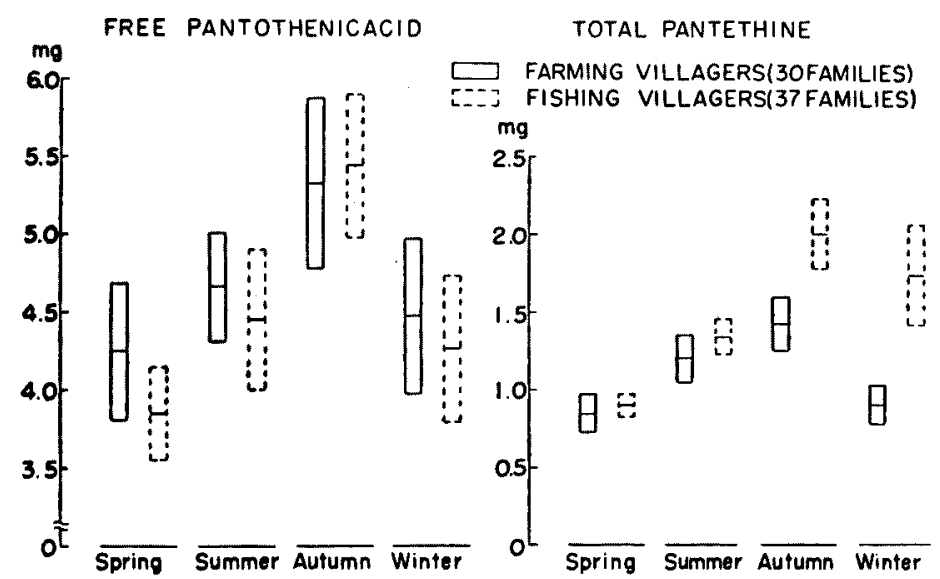

Fig. 1. Seasonal variation of the intake of pantothenic acid of the farming and fishing villagers. (mg/day, adult)

The upper and lower limits of means show twice as much as standard errors.

the major sources of total pantethine were different by place. In the farming village, nearly half of the intake came from vegetables, 15-20 per cent of it from fishes and 10-20 per cent from legumes, while in the fishing village, only 25-40 per cent of the intake was derived from vegetables, the intake from fishes rising far above that in the farming village, except in autumn, when it was indeed larger than in the farming village but not so significantly. Especially in winter, the fishers depended upon fishes and shell-fishes for over half of their total pante- 
TABLe II. Seasonal Variation of the Intake of Pantothenic Acid from Each Food Group at the Farming and Fishing Village (mg/day, adult)

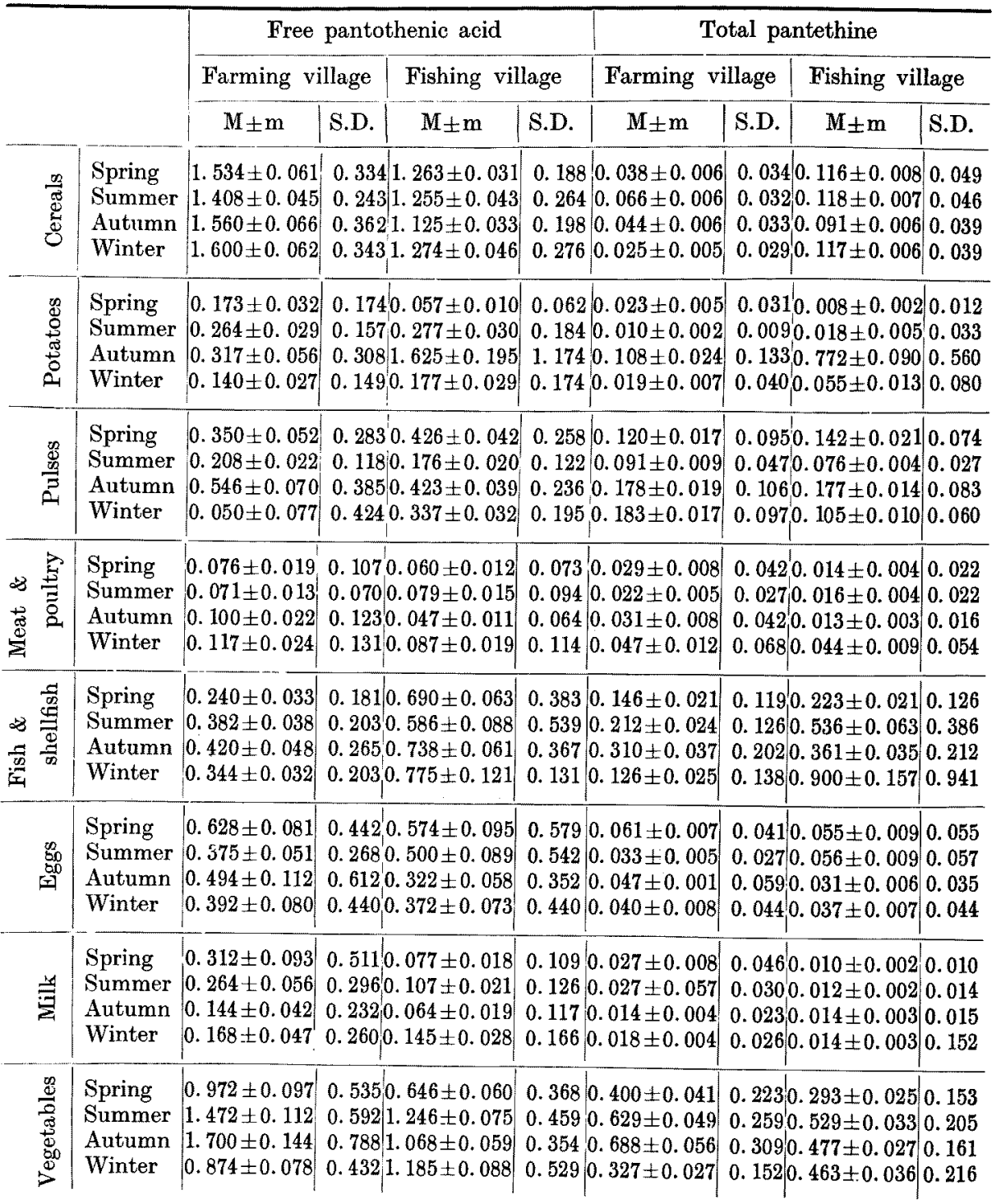

thine intake. The intake from potatoes in autumn was 38 per cent of it. It was also comfirmed that cereals may be good sources of free $\mathrm{Pa} \mathrm{A}$ but not good for supplying total pantethine, except when the cereal is unpolished. 
TABLE III. Seasonal Variation of the Intake of Pantothenic Acid from Each Food Group at the Farming and Fishing Villages (\%)

A. Free pantothenic acid

\begin{tabular}{l|r|r|r|r|r|r|r|r}
\hline & Cereals & Potatoes & Pulses & $\begin{array}{r}\text { Meat \& } \\
\text { poultry }\end{array}$ & $\begin{array}{r}\text { Fish \& } \\
\text { shellfish }\end{array}$ & Eggs & Milk & $\begin{array}{c}\text { Vegeta- } \\
\text { bles }\end{array}$ \\
\hline \multirow{2}{*}{ Spring } & 36.1 & 4.1 & 8.2 & 1.8 & 5.6 & 14.6 & 7.3 & 22.7 \\
& 32.9 & 1.5 & 11.1 & 1.6 & 18.0 & 14.9 & 2.0 & 16.8 \\
Summer & 30.2 & 5.7 & 4.5 & 1.5 & 8.2 & 8.1 & 5.7 & 30.6 \\
& 28.1 & 6.2 & 3.9 & 1.8 & 13.1 & 11.2 & 2.4 & 27.9 \\
Autumn & 29.3 & 6.9 & 10.2 & 1.8 & 7.9 & 9.3 & 2.7 & 31.8 \\
& 20.6 & 29.7 & 7.7 & 0.9 & 13.5 & 5.9 & 1.2 & 19.5 \\
Winter & 35.7 & 3.1 & 11.2 & 2.6 & 8.7 & 9.8 & 3.8 & 19.5 \\
& 29.8 & 4.1 & 7.9 & 2.0 & 18.2 & 7.7 & 2.4 & 27.8
\end{tabular}

B. Total pantethine

\begin{tabular}{l|r|r|r|r|r|r|r|r}
\hline Spring & 4.4 & 2.7 & 14.0 & 3.1 & 17.3 & 7.1 & 3.2 & 46.5 \\
& 13.0 & 0.9 & 16.0 & 1.6 & 25.1 & 6.2 & 1.1 & 39.2 \\
Summer & 5.5 & 0.8 & 7.6 & 1.9 & 17.7 & 2.7 & 2.3 & 52.4 \\
& 8.7 & 1.3 & 5.6 & 1.2 & 39.4 & 4.1 & 0.8 & 38.9 \\
Autumn & 3.1 & 7.6 & 12.5 & 2.1 & 21.8 & 3.3 & 1.0 & 48.5 \\
& 4.6 & 38.6 & 8.9 & 0.6 & 18.1 & 1.6 & 0.7 & 23.4 \\
Winter & 2.8 & 2.1 & 25.6 & 5.3 & 14.2 & 4.5 & 2.0 & 36.7 \\
& 6.7 & 3.1 & 6.1 & 2.5 & 52.3 & 2.1 & 0.8 & 26.0
\end{tabular}

The upper and lower numbers in each column indicate those of farming and fishing villagers respectively.

\section{DISCUSSION}

It is not new that pantothenic acid has been taken up as a variety of vitamins of B group. As stated in the previous report, this vitamin is present in nearly all food articles and few cases of its deficiency have been ever reported. However, in respect of the mechanism of biosynthesis of coenzymes, it seems likely that it is not free $\mathrm{Pa} \mathrm{A}$ but pantetheine (pantethine) that takes the place corresponding to that of thiamine, riboflavine, niacin and pyridoxin. Furthermore, if we take the decrease of $\mathrm{Pa} \mathrm{A}$ in blood in advanced age, it may be deduced that in the age when the liver function is on the decline, more attention should be given to the intake of derivatives of and above the pantetheine level rather than to that of $\mathrm{Pa}$ A itself. It may be possible that such ingested derivatives are decomposed by hepatic peptidase to produce $\mathrm{Pa} \mathrm{A}$ which is utilized in the process of Co A synthesis (this point for future research). Of cource, intake of $\mathrm{Pa} \mathrm{A}$ is not the sole question in discussing the extremely complicated functions of a living organism, but the present author wishes to point out that the agricultural village surveyed belongs to the area of mono-riceculture where the percentage of high-aged inhabitants is low, ${ }^{2}$ ) while in the fishing village surveyed, percentage of high-aged 
villagers both male and female, is rather high. ${ }^{3)}$

\section{SUMMARY}

The intake of free pantothenic acid in a farming village showed no differences from that in a fishing village in Miyagi prefecture, Japan, but the intake of its derivatives of and above the pantetheine level was larger in the fishing village, particularly in autumn and winter.

The intake was largest in autumn in both the villagers. The main sources of $\mathrm{Pa} \mathrm{A}$ and its derivatives were vegetables and fishes (including shellfishes). However cereals proved to be poor sources of pantetheine and its higher derivatives.

The auther expresses his thanks to Prof. E. Takahashi and Dr. S. Kamiyama who have given valuable suggestions.

\section{References}

1) Ishiguro, K., Tohoku J. Exper. Med., 1963, 78, 375.

2) Ohba, E., Jap. J. Race Hygiene (Jap.), 1959, 25, 140.

3) Itô, U. ibid., 1959, 25, 542 . 